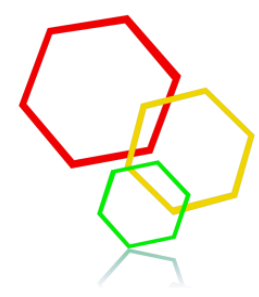

Journal of Chemistryand Technologies

pISSN 2663-2934 (Print), ISSN 2663-2942 (Online)

journal homepage: http://chemis try.dnu.dp.ua

UDC 66.96

\title{
INFLUENCE OF MULTIFUNCTIONAL MODIFICATION ON STABILIZATION OF CHEMICAL COMPOSITION OF WHEEL STEELS
}

\author{
Sergiy 0. Polishko \\ Oles Honchar Dnipro National University \\ Received 26 January 2019; accepted 3 April 2019; available online 9 June 2019
}

\begin{abstract}
This article deals with the impact of the chemical elements of the multifunctional modifier on the stabilization of chemical composition of the wheel steels KP-2 and KP-T. Increasing of the level of mechanical characteristics of such steels have been considered. Also, the causes of instability of the chemical composition of the wheel steel for locomotives of the class " $C$ » have been studied. It has been established, that the injection of the multifunctional modifiers into the steel melt caused the increasing of the stability of chemical composition and the level of mechanical characteristics of steel. The systematic thermodynamic investigations of the probable influence of the components of specific modifiers on the melt have been carried out. The basic thermodynamic parameters of compounds, formed in the melt of steels after the injection of special modifiers have been determined. It has been established, that modification contributes to the improvement of the morphology of nonmetallic inclusions in the investigated steels, which-causes the increasing of the mechanical characteristics of the ones.
\end{abstract}

Key words: chemical composition; stabilization; wheeled steels; non-metallic inclusions; thermodynamic and mechanical characteristics.

\section{ВПЛИВ БАГАТОФУНКЦІОНАЛЬНОГО МОДИФІКУВАННЯ НА СТАБІЛІЗАЦІЮ ХІМІЧНОГО СКЛАДУ КОЛІСНИХ СТАЛЕЙ}

\author{
Сергій 0. Полішко \\ Дніпровський національний університет імені Олеся Гончара, просп. Гагаріна, 72, Дніпро, 4901 0. Україна
}

\begin{abstract}
Анотація характеристики.

\footnotetext{
* Corresponding author: e-mail: polishkopsa@gmail.com

(C) 2018 Oles Honchar Dnipro National University

doi: $10.15421 / 081903$
}

У даній статті розглядається вплив багатофункціонального модифікатора на стабілізацію хімічного складу колісних сталей КП-2 і КП-Т. Розглянуто підвищення рівня механічних характеристик таких сталей. Також були вивчені причини нестабільності хімічного складу колісної сталі для колеса для локомотивів класу «С». Установлено, що введення багатофункціональних модифікаторів в сталевий розплав призводить до підвищення стабільності хімічного складу і рівня механічних характеристик. Проведені систематичні термодинамічні дослідження можливого впливу компонентів специфічних модифікаторів на розплав. Визначені основні термодинамічні параметри сполучених, що утворюють розплави сталей після введення спеціальних модифікаторів. Встановлено, що модифікація здатна поліпшити морфології неметалічних функцій в досліджуваних сталях, що також призводить до підвищення їх механічних характеристик.

Ключові слова: хімічний склад; стабілізація; колісні сталі; неметалеві включення; термодинамічні та механічні 


\title{
ВЛИЯНИЕ МНОГОФУНКЦИОНАЛЬНОГО МОДИФИЦИРОВАНИЯ НА СТАБИЛИЗАЦИЮ ХИМИЧЕСКОГО СОСТАВА КОЛЕСНЫХ СТАЛЕЙ
}

\author{
Сергей А. Полишко \\ Днипровский национальный университет имени Олеся Гончара, просп. Гагарина, 72, Днипро, 49010. Украина
}

\begin{abstract}
Аннотация
В данной статье рассматривается влияние многофункционального модификатора на стабилизацию химического состава колесных сталей КП-2 и КП-Т. Рассмотрено повышение уровня механических характеристик таких сталей. Также были изучены причины нестабильности химического состава колесной стали для колес для локомотивов класса «С». Установлено, что введение многофункциональных модификаторов в стальной расплав приводила к повышению стабильности химического состава и уровня механических характеристик стали. Проведены систематические термодинамические исследования вероятного влияния компонентов специфических модификаторов на расплав. Определены основные термодинамические параметры соединений, образующихся в расплаве сталей после введения специальных модификаторов. Установлено, что модифицирование способствует улучшению морфологии неметаллических включений в исследуемых сталях, что также приводит к повышению их механических характеристик.
\end{abstract}

Ключевые слова: химический состав, стабилизация, колесные стали, неметаллические включения, термодинамические и механические характеристики.

\section{Introdution}

Wheel steel in the modern conditions of production is a multicomponent system. But to date, many problems of transporting the metal have not been solved. Studies of the measurement of the crystallographic texture of a set of rail wheel steel samples with different regimes of thermo-mechanical treatment and with and without modification by system $\mathrm{Al}-\mathrm{Mg}$ Si- Fe-C-Ca-Ti-Ce for improving the quality of finished products have been carried out[1]. Also, such tasks as significant interlacing and in-situ spread (within the same fusion without any violation of normative documentation) of the chemical composition remain unresolved. This leads to a decreasing of the dispersion of the structure, the coarsening of the morphology of nonmetallic inclusions, the destabilization of mechanical characteristics and the not predictable decreasing of performance of the wheel steels. Despite the use of technologies for evacuation of alloys in the liquid state, the using of continuous casting, the processing of melts by aluminum rod of various ligatures such as $\mathrm{FeSi}$, FeMn, SiMn, FeV, FeMo, SiCa, $\mathrm{Al}, \mathrm{CaO}, \mathrm{CaF}_{2}$ and others, the problem of stabilizing of the chemical composition and improving the quality of the finished wheels remains relevant [2-4].

\section{Results and its discussion}

Improving the characteristics and the structure is possible by using deoxidation, modification, microalloying and refining of the steel melt in the liquid state and heat treatment in the solid state. However, the most progressive way to improve the quality of carbon steels is to treat them in a liquid state [5-10].

In recent years the multifunctional modification has been actively used in the industry. As a result of this process, the level of mechanical characteristics of various materials is has been increased. To solve the problem of the instability of the chemical composition of various alloys it was proposed to modify the melts of low-alloyed alloys with nanodispersed compositions obtained by plasma-chemical synthesis. In the same time a significant (in 2 ... 3.5 times) grain refinement and stabilization of the alloy structure as a result of nanopowder modification of titanium carbonitride has been achieved [8-16].

In connection with the above, pilot-industrial smelting with the use of multifunctional modifiers was carried out in "INTERPIPE NTZ" [17]. Wheel steels of grades KP-T, KP-2 and class «C» were smelted in the 100 ton unit of a ladle furnace. After this, the array of data from the chemical composition and mechanical characteristics of these brands of wheel steels of the open-hearth and electric steelmaking modes was collected and systematized to determine the degree of instability of each of the characteristics of the transported metal. To do this, the coefficients of variation in the chemical composition of the steels were determined (Table 1). As is known, the lower is the coefficient of variation, the more stable is the system.

The results in the table 1 show the average concentrations of components and the coefficients of variation of their values. The coefficients have small values for the content of 
Journal of Chemistry and Technologies, 2019, 27(1), 31-39

the main alloying elements of both the serial and modified steels. At the same time, in the serial metal these coefficients for harmful impurities (S and $\mathrm{P}$ ) are significant and range from 0.01 to 0.30 for sulfur and 0.01 to 0.34 for phosphorus. In the modified metal, such coefficients are lower: from 0.01 to 0.15 for sulfur and from 0.01 to 0.30 for phosphorus. These impurities occur in different amounts in almost all the materials of the charge, which was used in the process of steel smelting and its secondary processing. The impurities are caused by the dispersion of their concentrations in the smelted steel [18].

Coefficients of variation of the residual concentrations of the elements in the modifier (Al and $\mathrm{Ti}$ ) range from 0.08 to 0.10 for titanium and from 0.02 to 0.23 for aluminum. At the same time, the variation coefficients in the modified metal are not that different, but are still lower: from 0.07 to 0.08 for titanium and from 0.05 to 0.09 for aluminum.

Indicators of stability of the chemical composition of wheeled serial and modified steels

\begin{tabular}{|c|c|c|c|c|c|c|c|c|c|c|c|c|}
\hline \multirow[t]{2}{*}{ Steel } & \multirow[t]{2}{*}{ Parameter } & \multicolumn{11}{|c|}{ Components } \\
\hline & & $\mathrm{C}$ & $\mathrm{Mn}$ & $\mathrm{Si}$ & $\mathrm{S}$ & $\mathrm{P}$ & $\mathrm{Cr}$ & $\mathrm{Ni}$ & $\mathrm{Cu}$ & $\mathrm{Ti}$ & $\mathrm{V}$ & $\mathrm{Al}$ \\
\hline \multirow[t]{8}{*}{ КП-2 } & Average & \multicolumn{11}{|c|}{ Serial } \\
\hline & & 0.60 & 0.74 & 0.34 & 0.01 & 0.01 & 0.07 & 0.05 & 0.06 & 0.01 & 0 & 0.03 \\
\hline & & \multicolumn{11}{|c|}{ Modified } \\
\hline & & 0.63 & 0.73 & 0.33 & 0.01 & 0.01 & 0.13 & 0.13 & 0.05 & 0.01 & 0.03 & 0.02 \\
\hline & Coefficients & \multicolumn{11}{|c|}{ Serial } \\
\hline & of variation & 0.03 & 0.01 & 0.05 & 0.27 & 0.08 & 0.17 & 0.12 & 0.14 & 0.09 & 0 & 0.10 \\
\hline & & \multicolumn{11}{|c|}{ Modified } \\
\hline & & 0.01 & 0.01 & 0.01 & 0.04 & 0.06 & 0.03 & 0.07 & 0.09 & 0.08 & 0.01 & 0.05 \\
\hline KP-T & Average & \multicolumn{11}{|c|}{ Serial } \\
\hline & & 0.66 & 0.76 & 0.31 & 0.01 & 0.01 & 0.19 & 0.13 & 0.06 & 0.01 & 0.10 & 0.02 \\
\hline & & \multicolumn{11}{|c|}{ Modified } \\
\hline & & 0.67 & 0.76 & 0.32 & 0.01 & 0.01 & 0.21 & 0.14 & 0.06 & 0.01 & 0.09 & 0.03 \\
\hline & \multirow{4}{*}{$\begin{array}{l}\text { Coefficient } \\
\mathrm{s} \text { of } \\
\text { variation }\end{array}$} & Serial & & & & & & & & & & \\
\hline & & 0.02 & 0.03 & 0.05 & 0.19 & 0.34 & 0.06 & 0.09 & 0.18 & 0.10 & 0.13 & 0.23 \\
\hline & & \multicolumn{11}{|c|}{ Modified } \\
\hline & & 0.02 & 0.01 & 0.03 & 0.15 & 0.30 & 0.03 & 0.10 & 0.31 & 0.07 & 0.04 & 0.09 \\
\hline \multirow[t]{3}{*}{ Class $« \mathrm{C} »$} & Average & \multicolumn{11}{|c|}{ Serial } \\
\hline & & 0.72 & 0.76 & 0.33 & 0.01 & 0.01 & 0.15 & 0.05 & 0.06 & 0.01 & 0 & 0.02 \\
\hline & $\begin{array}{l}\text { Coefficients } \\
\text { of variation }\end{array}$ & 0.02 & 0.03 & 0.06 & 0.30 & 0.33 & 0.13 & 0.24 & 0.31 & 0.08 & 0 & 0.16 \\
\hline
\end{tabular}

To determine the reasons for the stabilization of the chemical composition, systematic thermodynamic studies have been carried out on the possible influence of the components of special modifiers in their interaction with the melt [19].

The key thermodynamic parameters of the compounds which can be formed in the fusion steels after the injection of special modifiers are shown in the fig. 1 - 3. Melting temperature, enthalpy and entropy of formation of carbides, nitrides, oxides and sulfides, which are submicroscopic compounds, arised in the fusion after the modifying with special deoxidizers is illustrated.

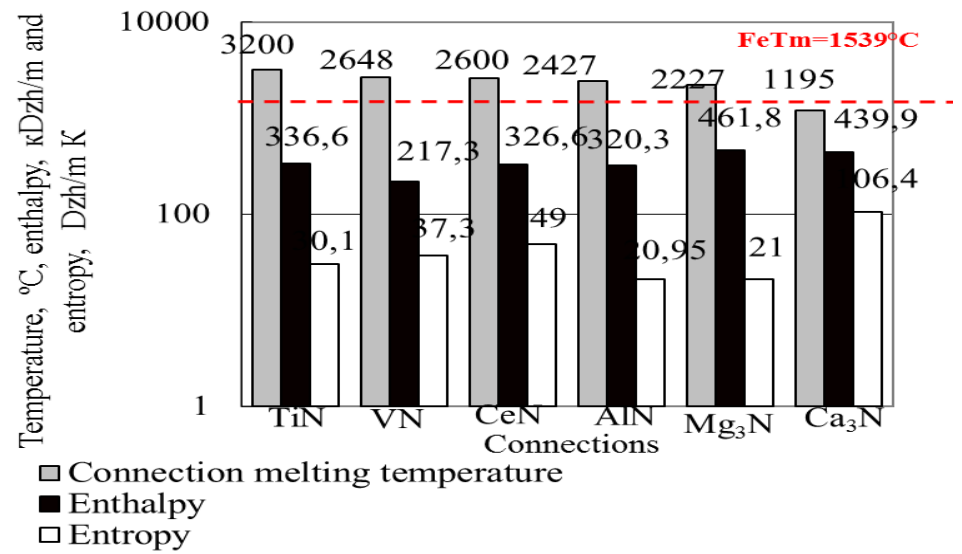

Fig. 1. Melting temperatures, enthalpy and entropy of formation of nitrides (half-logarithmic scale) 
Journal of Chemistry and Technologies, 2019, 27(1), 31-39

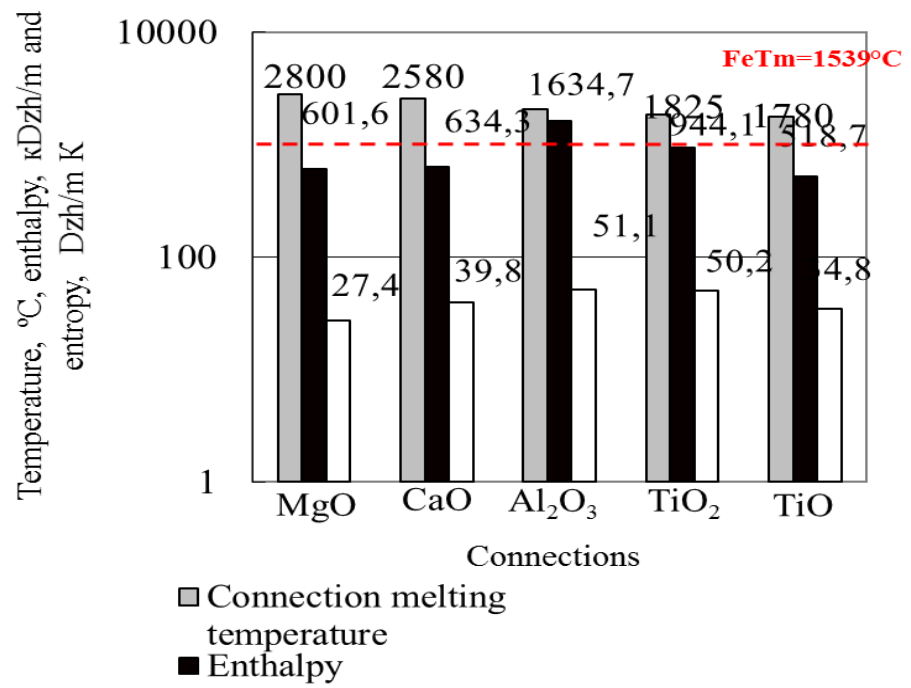

Fig. 2. Melting temperatures, enthalpy and entropy formations of oxides (half-logarithmic scale)

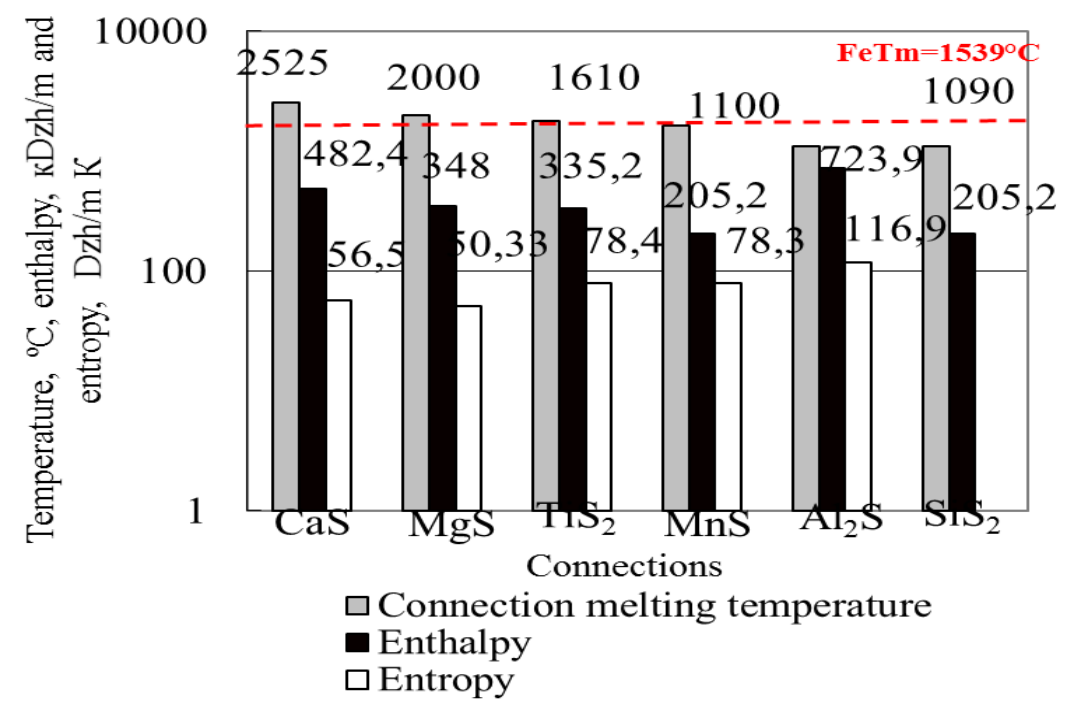

Fig. 3 - Melting temperatures, enthalpy and entropy of formation of sulfides (half-logarithmic scale)

The red dotted line indicates the iron melting temperature - $1539{ }^{\circ} \mathrm{C}$. If the formed compound has a higher melting temperature than the steel it becomes the center of crystallization and could be related to the modifier of a sort II (by the inoculation mechanism). However, it is also important to know the values of enthalpy and entropy to define the stability of a compound as modifier. As it can be seen in the fig. 1-3, the following compounds have an optimum combination of three key thermodynamic parameters: $\mathrm{TiN}, \mathrm{VN}, \mathrm{CeN}, \mathrm{AlN}, \mathrm{Mg}_{3} \mathrm{~N}_{2}, \mathrm{CaO}, \mathrm{MgO}$, $\mathrm{Al}_{2} \mathrm{O}_{3}, \mathrm{TiO}_{2}, \mathrm{TiO}, \mathrm{CaS}, \mathrm{TiS}_{2}, \mathrm{MnS}, \mathrm{MgS}$, TiS, CaS [2027].

According to the formation of a large number of stable submicroscopic compounds, it is possible to expect the increasing of chemical uniformity of the metal. Usually, the crystallization expands from a mold wall in an ingot by the growth of dendrites, the great bulk of which sprout deeply into in the direction of an axis of the ingot where there is a significant amount of non-metallic inclusions where the steel crystallizes. There is the homogeneous grain here, as shown on the scheme. After the modifying there are formed the centers of crystallization as a result of interaction of special multicomponent deoxidizing modifiers with the steel fusion. They are proportionally distributed in the metal because of the special physical and chemical characteristics, structure of deoxidizing modifiers, constancy of their geometrical form and weight. When an ingot hardens, it generally takes place the volume crystallization, not oriented on the heat sink. The dominance of the volume mechanism of crystallization is one of basic reasons of stabilization of chemical 
Journal of Chemistry and Technologies, 2019, 27(1), 31-39

composition of the steels, modified by special deoxidizing modifiers [28-31].

Modifying has led to improvement of morphology of non-metallic inclusions. The structure and morphology of non-metallic inclusions were investigated on the scanning JEOL JSN-6360LA electron microscope equip ped with the JED-2300 system. The results are represented on fig. 4 (table 2, 3).

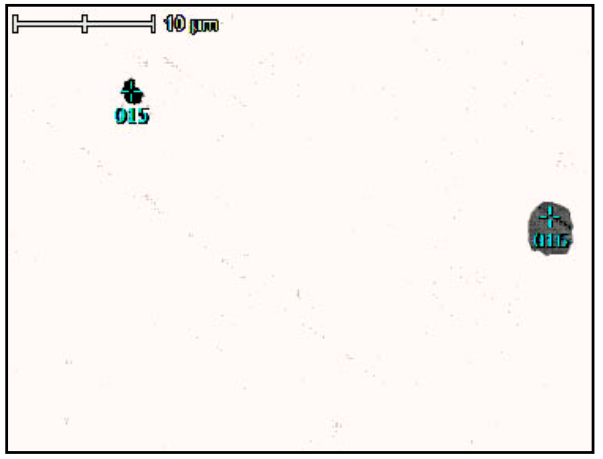

a

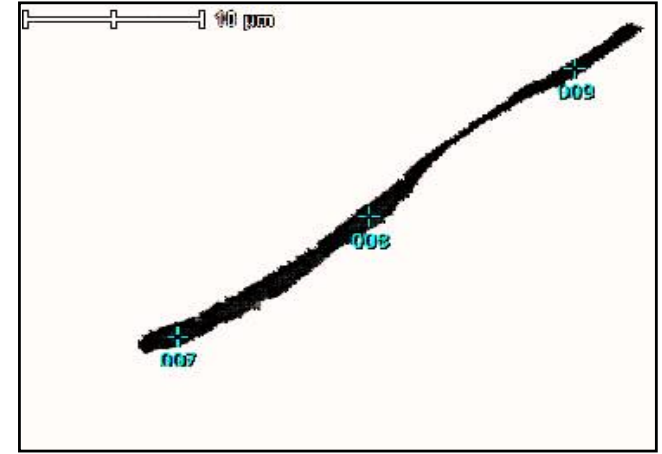

b

Fig. 4. Non-metallic inclusions in the serial and modified KP-T steel, h3000

Structure of non-metallic inclusions of the modified KP-T steel

\begin{tabular}{llllllll}
\hline № point & 0 & $\mathrm{Si}$ & $\mathrm{S}$ & $\mathrm{Ca}$ & $\mathrm{Mn}$ & $\mathrm{Fe}$ & Amount,\% \\
\hline 015 & 0 & 0 & 31.2 & 6.3 & 62.5 & 0 & 100 \\
\hline 016 & 0 & 0 & 33.6 & 2.8 & 63.7 & 0 & 100 \\
\hline
\end{tabular}

Structure of non-metallic inclusions of the KP-T serial steel

\begin{tabular}{lllll}
\hline № point & $\mathrm{S}$ & $\mathrm{Mn}$ & $\mathrm{Fe}$ & Amount,\% \\
\hline 007 & 29,84 & 61,79 & 8,38 & 100 \\
\hline 008 & 28,67 & 57,41 & 13,93 & 100 \\
\hline 009 & 26,26 & 57,72 & 16,03 & 100 \\
\hline
\end{tabular}

The data obtained confirm that the nonmetallic inclusions in the modified steel even after magnification have the globular structure and do not act as the concentrators of tension. Also, the modification caused the increasing of the mechanical characteristics of modified steels of grades KP- 2 and KP-T, as can be seen on the tables 4 and 5 .

It was determined that the obtained characteristics of the modified KP-T steel are higher than the characteristics of the serial steel of the same grade: in 1.02 times in the tensile strength $\sigma \mathrm{B}$, in 1.14 times in the KCU toughness, in 1.02 times in the relative elongation $\delta, \psi(?)$ in 1,06 times (what exactly number?), and in 1,006 times in hardness.

The mechanical characteristics of the lowcarbon constant, both serial and modified, are given in Table 4, 5 .

The value of the mechanica characteristics of modified steels is higher than their value in the serial metal. This ensures a higher reliability of reinforced concrete and wheels, being used in construction of vehicles due to the increasing of the level of mechanical characteristics. 
Journal of Chemistry and Technologies, 2019, 27(1), 31-39

Mechanical characteristics of serial and modified steel KP-2

\begin{tabular}{|c|c|c|c|c|c|c|}
\hline \multirow{2}{*}{ Type } & \multirow{2}{*}{$\sigma_{\text {в, }}$ MPA } & \multirow{2}{*}{$\delta, \%$} & \multirow{2}{*}{$\psi, \%$} & \multirow{2}{*}{$\begin{array}{l}\text { НВ30, } \\
\text { МПа }\end{array}$} & \multicolumn{2}{|c|}{$\mathrm{KCU}, \mathrm{Dzh} \mathrm{m} / \mathrm{cm}^{2}$} \\
\hline & & & & & rim & drive \\
\hline Requirements & $\begin{array}{l}1020- \\
1180\end{array}$ & $\geq 9$ & $\geq 16$ & $\begin{array}{l}3200- \\
3600\end{array}$ & $\geq 18$ & $\geq 20$ \\
\hline \multicolumn{7}{|l|}{ Serial } \\
\hline Average & 1000 & 11,5 & 21 & 2910 & - & 25 \\
\hline Coefficients of variation & 0,02 & 0,07 & 0,1 & 0,03 & - & 0,15 \\
\hline \multicolumn{7}{|l|}{ Modified } \\
\hline Average & 1052 & 11,5 & 22,9 & 2982 & - & 29 \\
\hline Coefficients of variation & 0,01 & 0,02 & 0,08 & 0,03 & - & 0,11 \\
\hline
\end{tabular}

Mechanical characteristics of serial and modified steel KP-T

\begin{tabular}{|c|c|c|c|c|c|c|}
\hline \multirow{2}{*}{ Type } & \multirow{2}{*}{$\sigma_{\mathrm{B}}, \mathrm{MPa}$} & \multirow{2}{*}{$\delta, \%$} & \multirow{2}{*}{$\psi, \%$} & \multirow{2}{*}{$\begin{array}{l}\text { НВ30, } \\
\text { МПа }\end{array}$} & \multicolumn{2}{|c|}{ KCU, Dzh m $/ \mathrm{cm}^{2}$} \\
\hline & & & & & rim & drive \\
\hline Requirements & $\begin{array}{l}1020- \\
1180\end{array}$ & $\geq 9$ & $\geq 16$ & $\begin{array}{l}3200- \\
3600\end{array}$ & $\geq 18$ & $\geq 20$ \\
\hline \multicolumn{7}{|l|}{ Serial } \\
\hline Average & 1132 & 11.1 & 22.9 & 3254 & 23 & 20 \\
\hline Coefficients of variation & 0.02 & 0.14 & 0.15 & 0.05 & 0.15 & 0.34 \\
\hline \multicolumn{7}{|l|}{ Modified } \\
\hline Average & 1153 & 11.2 & 26.2 & 3273 & 27 & 24 \\
\hline Coefficients of variation & 0.01 & 0.08 & 0.11 & 0.03 & 0.15 & 0.28 \\
\hline
\end{tabular}

\section{Conclusions}

It was set that the effect of multifunctional modifiers provides a reduction of the content of non-metallic inclusions and stabilization of both the chemical composition and the level of mechanical characteristics of the KP-T wheel steel. The results prove that modifying is the most effective way of eliminating such essential drawback as instability of the chemical composition. The reduction of the content of harmful impurities such as phosphorus and sulfur, undoubtedlyleads to the improvem ent of the quality of the finished wheels. Stabilized chemical composition and mechanical characteristics plays an important role in the usage of the ready-made wheels. Modification without significant additional costs ensures the stabilization of the chemical composition and characteristics of steel and is possible by the implementation of the mechanism of bulk crystallization of the melt, reduction of liquation, grinding of structural components.

\section{Бібліографічні посилання}

[1] Investigation of rail wheel steel crystallographic texture changes due to modification and thermomechanical treatment / A.F. Sanin, T.A.Lychagina, D.I. Nikolayev, J.V.Tatarko // IOP Conference Series Materials Science and Engineering. - 2015. - P. 1-6.

[2] Полішко, С.О. Комплексное влияние вредных примесей (S, P, As) и основных легирующих элементов на механические свойства стали Ст1кп / C.O. Полішко // Системне проектування та аналіз характеристик аерокосмічної техніки: Вип. 1. Зб. наук. праць. - 2015. - Т. 18. - С. 7883.

[3] Polishko S. A. Effect of modification on the formation of nonmetallic inclusions in kp-t wheel steel TM / S. A. Polishko // Техническая механика. - 2017. - № 4. - P. 111-114.

[4] Модифицирование стали и сплавов редкоземельными элементами. / Л.А. Смирнов, В.А. Ровнушкин, А.С. Орыщенко [и др.] // Металлург. - 2016. - № 1. - С. 41-48.

[5] Интеграция элементов наружной трехслойной панели теплозащитной конструкции многоразовых космических аппаратов// Т.А. Манько, И.А. Гусарова, А. М. Потапов [и др.] // Журнал Автоматическая сварка. - 2017. - № 3. - С. 76-81.

[6] Влияние шпатових материалов на измельчение структуры алюминия дисперсными композициями 
Journal of Chemistry and Technologies, 2019, 27(1), 31-39

// Н.Е. Калинина, Т.В. Носова, М.В.Грекова, М.В. Гученков // Вестник двигателестроения. - 2017. №2 - C. 116-122

[7] Влияние микролегирования и модифицирования на структурное упрочнение и свойства сплавов // H.Е Калинина, Т.В. Носова, А.В.Давидюк, О.П. Юшкевич // Системне проектування та аналіз характеристик аерокосмічної техніки. - 2016. - Т. 22. - С. 79-84.

[8] Носова Т.В. Получение нанодисперсных модификаторов плазмохимическим синтезом / Т.В.Носова, А.В.Калинин // Вестник двигателестроения. - 2017. - №1 - С. 63-37.

[9] Ресурсосберегающая технология изготовления шаробаллонов из титановых сплавов / Н.Е.Калинина, Т.В.Носова, М.В. Грекова, А.В.Кашенкова // Вестник двигателестроения. 2017. - №1 - C. 43-47.

[10] Investigation of the influence of nanodispersed compositions obtained by plasmochemical synthesis on the crystallization processes of structural alloys / Y.Dzhur, N. Kalinina, M. Grekova, M. Guchenkov // Eureka: physics and engineering.- 2017. - №6. - P. 6368.

[11] Investigation of the influence of nanodispersed compositions obtained by plasmochemical synthesis on the crystallization processes of structural alloys / Y.Dzhur, A. Kalinin, M. Grekova, M. Guchenkov // Eureka: physics and engineering. - 2017. - № 6. - P. 5661.

[12] Санин А.Ф. Исследования по разработке способа получения порошков алюминиевых сплавов для изготовления заготовок с высокими конструкционными свойствами. / А.Ф. Санин, А.Ф. Леднянский, М.В. Приходько // Системне проектування та аналіз характеристик аерокосмічної техніки. - 2015. - Т. 17. - С. 69-74.

[13] Санин А.Ф. Формирование ячеистой субструктуры в дисперсноупрочненном алюминиевом сплаве. / А.Ф. Санин, К.В. Бечке, А.Д. Тулегулов // Хабарши-Вестник Евразийского национального университета им. Л.Н. Гумилева. - 2015. - Вып 6, Т.1. - С. 73-81.

[14] Санин А.Ф. Основы металлургического производства концевого режущего инструмента / А.Ф. Санин, В.П.Бобылев, В.А. Доморацкий // Теория и практика металлургии. - 2015. - Вып 2. - С. 95-98.

[15] Изготовление прецизионных корпусных деталей ракетного вооружения из алюминиевых сплавов / А.Ф. Санин, О.В. Бондаренко, Ю.П. Бунчук, М.В. Приходько // Збірник наукових праць Харківського університету повітряних сил. - 2015. - Вип. 1 (8) C. 115-120.

[16] Джур о.€. Напрямки удосконалення підприємницьких структур в космічній галузі / о.Є. Джур // ЕКОНОМІКА: реалії часу. - 2015. - Вип №6. - С. 62-70.

[17] Пат 93684 Україна МПК (2011.01) С22C 35/00 С21С 7/04. Розкислювач-модифікатор для обробки розплавів сталей і сплавів. / О.М Шаповалова, В.П. Шаповалов, Шаповалов О. В., Полішко С. O. Заявник та патентоутримувач Дніпропетровський національний університет імені Олеся Гончара. №a200801124, заявл. 30.01.2008 р., опубл. 10.03.2011 p. - Бюл №5.

[18] Полішко С.О. Влияние модифицирования на распределение легирующих элементов в микрообъемах малоуглеродистой стали Ст1кп // С.О.Полішко // Вісник Дніпропетровського національного університету імені Олеся Гончара.
Серія Ракетно-космічна техніка. - 2016. - Вып. 1. C. 115-119.

[19] Полішко С.О. Влияние элементов-модификаторов на свойства колесной стали марки КП-Т. / С.О. Полішко // Системне проектування та аналіз характеристик аерокосмічної техніки. - 2016. - Вип. 20. - С. 49-54.

[20] Полішко С.О. Влияние модифицирования многофункциональными модификаторами на структуру и свойства колесных сталей // С.О. Полішко // Первый независимый научный вестник. - 2016. - Вып № 6. - С. 87-96.

[21] Бечке К.В. Определение параметров распыления, обеспечивающих максимальную скорость охлаждения частиц порошка алюминиевого сплава / К.В. Бечке, А.Ф. Санин, М.А. Шандрыга // Современное материаловедение: опыт, проблемы и перспективы развития. - 2015. - С. 81-83.

[22] Джур о.Є. Державне регулювання підприємствами космічної галузі України: нові реалії та виклики / о.Є. Джур // Ефективна економіка. - 2015. - № 1. С. $35-42$.

[23] Приходько М.В. Вопросы прочности и жаропрочности алюминиевых сплавов для транспортного машиностроения / М. В. Приходько, А.Ф. Леднянский, А.Ф. Санин // Вестник Евразийского национального университета им. Л.Н. Гумилева. Серия Естественно-технических наук. 2016. - Вып №2. - С. 301-307.

[24] Джур 0.Є. Ієрархія стратегічних намірів в управлінні конкурентоспроможністю підприємства космічної галузі / о.Є. Джур// Ефективна економіка. - 2016.№11. - С. 125-132.

[25] Проектирование размеростабильных оболочечных конструкций из композиционных материалов / А.В. Кулик, С.И. Москалев, А.Ф. Санин, А.П. Щудро // Механика гироскопических систем. - 2016. - №31. C. $115-120$.

[26] Обгрунтування вибору скандію для мікролегування і модифікування високоміцних алюмінієвих сплавів / Н.Є. Калініна, О.П. Юшкевич, В.Т. Калінін, М.В.Грекова // Строительство, материаловедение, машиностроение. - 2017. - Вип. 95.- С. 93-99.

[27] Полишко С.А. Влияние модифицирования на стабилизацию химического состава и повышение уровня механических свойств колесной стали марки КП-2 / С.А. Полишко // Системне проектування та аналіз характеристик аерокосмічної техніки. - 2017. - Вып. 22. - С. 25-32.

[28] Полишко С.А. Стабилизация химического состава при выплавке колесной стали класса «С» // С.А. Полишко // Вісник Дніпровського національного університету імені Олеся Гончара. Серія: Ракетнокосмічна техніка. - 2017. - Вып.1. - С. 62-68.

[29] Полишко С.А. Влияние химического состава колесной стали марки R7 на механические свойства при парной и групповой корреляциях / C.A. Полишко // Системне проектування та аналіз характеристик аерокосмічної техніки. - 2017. - Вып 24. - С. 56-61.

[30] Полішко С.О. Влияние модифицирования на структуру и распределение основных легирующих элементов в микрообъемах малоуглеродистой стали Ст1кп / C. О. Полішко // Металлознавство та термічна обробка металів. - 2015. -Вып 68, ч.1. - С. $52-59$.

[31] Полішко С.О. Неметаллические включения в малоуглеродистых сталях / C.O. Полішко // Системне проектування та аналіз характеристик аерокосмічної техніки. - 2015. - Вып 19. - С. 153-158. 
Journal of Chemistry and Technologies, 2019, 27(1), 31-39

References

[1] Sanin, A.F., Lychagina, T.A., Nikolayev, D.I., Tatarko, J.V., Sanin, A.F. (2015). Investigation of rail wheel steel crystallographic texture changes due to modification and thermomechanical treatment. IOP Publishing Conf. Series: Materials Science and Engineering, 1-6. http://dx.doi.org/ 82. 0.1088/1757-899X/82/1/012107

[2] Polishko, S.O. (2015). [Complex influence of harmful impurities (S, P, As) and basic alloying elements on the mechanical properties of steel St1kp]. Systemne proektuvannja ta analiz kharakterystyk aerokosmichnoji tekhniky, 1(18), 78-83 (in Ukrainian).

[3] Polishko, S. A. (2017). [Effect of modification on the formation of nonmetallic inclusions in KP-T wheel steel TM]. Tekhnycheskaja mekhanyka, 4, 111-114. http://dx.doi.org/ 10.15587/2312-8372.2019.157676

[4] Smirnov, L.A. Rovnushkin VA, Oryshchenko AS, Kalinin G. Yu., Milyutz V. G. (2016). [Modification of steel and alloys by rare earth elements]. Metalurg, 1, 41-48 (in Russian).

[5] Manko, T.A., Gusarova I.A. (2017) [Integration of elements of the outer three-layer panel of the heatshielding design of reusable space vehicles]. Avtomatycheskaja svarka, 3, 76-81.

[6] Kalinina, NE, Nosova, T.V., Grekova, M.V., Guchenkov, M.V. (2017). [Influence of shpatovih materials on the grinding of the structure of aluminum by dispersed compositions]. Vestnyk dvyghatelestroenyja, (2), 116-122 (in Russian).

[7] Kalinina, N.E., Nosova, T.V., Davidyuk, A.V, Yushkevich, O.P. (2016). [Influence of microalloying and modifying on structural hardening and properties of alloys]. Systemne proektuvannja ta analiz kharakterystyk aerokosmichnoji tekhniky, 22, 79-84 (in Russian).

[8] Nosova, T.V., Kalinin, A.V. (2017). [Preparation of nanodispersed modifiers by plasma-chemical synthesis]. Vestnyk dvyghatelestroenyja, 1, 63-37 (in Russian).

[9] Kalinina, N.E., Nosova, T.V. Grekova, M.V., Kashenkova, A.V. (2017). [Resource-saving technology of manufacturing of balloons from titanium alloys]. Vestnyk dvyghatelestroenyja, 3(1), 43-47.

[10] Dzhur, Y., Kalinina, N., Grekova, M., Guchenkov, M. (2017). Investigation of the influence of nanodispersed compositions obtained by plasmochemical synthesis on the crystallization processes of structural alloys. Eureka: physics and engineering, 6, 63-68.

[11] Dzhur, Y., Kalinin, A., Grekova, M., Guchenkov, M. (2017). [Investigation of the influence of nanodispersed compositions obtained by plasmochemical synthesis on the crystallization processes of structural alloys]. Eureka: physics and engineering, 6, 56-61. http://dx.doi.org/ 10.21303/2461-4262.2017.00500

[12] Sanin, A. Lednyansky, A., Prikhodko, M. (2015). [Studies on the development of a method for producing aluminum alloy powders for the production of billets with high structural properties]. Systemne proektuvannja ta analiz kharakterystyk aerokosmichnoji tekhniky, 17, 69-74 (in Russian). http://dx.doi.org/ 10.21303/2461$\underline{4262.2017 .00500}$

[13] Sanin, A., Bechke, K., Tulegulov K. (2015). [Formation of a cellular substructure in a dispersion-reinforced aluminum alloy]. Khabarshy-Vestnyk Evrazyjskogho nacyonaljnogho unyversyteta ym. L.N. Ghumyleva, 1(6), 73-81 (in Russian).

[14] Sanin, A. Bobylev V., Domoratsky, V. (2015). [Basis of metallurgical production of the end cutting tool]. Teoryja y praktyka metallurghyy, (2), 95-98 (in Russian).
[15] Sanin, A., Bondarenko, O., Bunchuk, Y., Prikhod'ko, M. (2015). [Production of precision hull details of rocket weapons from aluminum alloys], Zbirnik naukovyh prac Kharkivskogo University unexplored forces, 1 (8), 115120 (in Russian).

[16] Dzhur, 0. (2015). [Directions of perfection of pidermont structures in the space domain]. EKONOMIKA: realy hour, 6, 62-70 (in Ukrainian).

[17] Shapovalova, O., Shapovalov, V., Shapovalov, O., Polishko, S. (2011). Ukraine Patent № 93684. Dnipropetrovsk, Ukraine. Oles Honchar Dnipropetrovsk National University.

[18] Polishko, S.O. (2016) [Influence of the modification on the distribution of alloying elements in the microvolumes of a non-carbon steel ST1kp]. Visn. Dnipr. nac. Univer. im. Olesja Ghonchara. Serija Raketno-kosmichna tekhnika, 1(16), 115-119 (in Russian).

[19] Polishko, S.O. (2016) [Influence of modifying elements on the properties of the KP-T wheel steel]. Systemne proektuvannja ta analiz kharakterystyk aerokosmichnoji tekhniky. 20, 49-54 (in Ukrainian).

[20] Polishko, S.O. (2016) [Influence of modification by multifunctional modifiers on the structure and properties of wheel steels]. Pervyy nezavisimyy nauchnyy vestnik, (6), 87-96 (in Ukrainian).

[21] Bechke, K, Sanin, A., Shandryga, M. (2015). [Determination of spray parameters providing the maximum rate of cooling of particles of aluminum alloy powder] Sovremennoye materialovedeniye: opyt, problemy i perspektivy razvitiya, 81-83 (in Russian).

[22] Dzhur, O.E. (2015). [State regulation by enterprises of the space industry of Ukraine: new realities and challenges]. Efektyvna ekonomika, 1, 35-42 (in Ukrainian).

[23] Prikhodko, M., Lednyansky, A., Sanin, A. (2016) [Problems of durability and heat resistance of aluminum alloys for transport machine building]. Vestnik Yevraziyskogo natsional'nogo universiteta im. L.N. Gumileva, 2, 301-307 (in Russian).

[24] Dzhur, O.E. (2016) [Hierarchy of Strategic Intent in Managing the Competitiveness of the Space Industry Enterprise]. Efektyvna ekonomika, 11, 125-132 (in Ukrainian).

[25] Kulik, A, Moskalev, S., Sanin, A. (2016) [Kindly Design of Dimensional Shell Structures from Composite Materials]. Mekhanika giroskopicheskikh sistem, 31, 115-120 (in Russian).

[26] Kalinina, N.E., Yushkevich, A., Kalinin, V., Grekov A. (2017) [Rationale for microalloying scandium and modification of high aluminum alloys]. Stroitel'stvo, materialovedeniye, mashinostroyeniye, 95, 93-99 (in Ukrainian).

[27] Polishko, S.A. (2017) [Effect on modyfytsyrovanyya stabilization of chemical composition and mechanical properties urovnja Increase kolesnoy steel grade KP-2]. Systemne proektuvannja ta analiz kharakterystyk aerokosmichnoji tekhniky, 22, 25-32 (in Russian).

[28] Polishko, S.A. (2017) [Stabilization of the chemical composition during the smelting of the wheel of the class "C"]. Visn. Dnipr. nac. univer. im. Olesja Ghonchara. Serija Raketno-kosmichna tekhnika, 1, 62-68 (in Russian).

[29] Polishko, S.A. (2017) [The Influence of the Chemical Composition of R7 Wheel Rolled on Mechanical Properties in Couple and Group Correlation]. Systemne proektuvannja ta analiz kharakterystyk aerokosmichnoji tekhniky, 24, 56-61 (in Russian).

[30] Polishko S.O. (2015) [Influence of modification on the structure and distribution of the main alloying elements 
Journal of Chemistry and Technologies, 2019, 27(1), 31-39

in the microcosm of the low-carbon steel St1kp]. Metalloznavstvo ta termichna obrobka metaliv, 68(1), 5259 (in Russian).

[31] Polishko, S.O. (2015) [Nonmetallic inclusions in lowcarbon steels]. Systemne proektuvannja ta analiz kharakterystyk aerokosmichnoji tekhniky, 19, 153-158 (in Russian). 